\title{
CORRESPONDENCE
}

\section{DIAGNOSTIC CONTACT LENS}

To the Editorial Committee of the British Journal of OpHTHALMOLOGY

DEAR SIRs-I should be grateful if you would publish the following addendum to my paper (Sarwar, 1954).

\section{GoNIOSCOPY}

Two methods can be employed to carry out this examination after insertion of the lens in an anaesthetized eye:

(1) Examination by Reflected Light.-A very narrow slit-lamp beam is projected on to the area of angle to be examined, with the eye looking slightly away from the direction of the beam. The beam is focused on the angle and the various structures in it, and the examination is carried out along the direction of the beam.

(2) Examination by Transmitted Light.-The slit-lamp beam is projected approximately on to the angle from the same side as the area of angle under examination. Two reflexes will be seen, one on the cornea and one on the iris. The beam is then moved outwards, and when the light is on the angle the two reflexes come close together, being separated only by the narrow space of the angle itself. The angle can thus be examined by transmitted light. This method is very useful for examining the trabecula and cells in the angle.

Yours faithfully,

M. SARWAR:

\section{REFERENCE}

SARWAR, M. (1954). British Journal of Ophthalmology, 38, 626.

\section{BOOK REVIEWS}

Current Concepts of Diabetes Mellitus with Special Reference to Ocular Changes. By L. Benjamin Sheppard. 1955. Pp. 90, 16 figs, 1 col. pl., 199 refs. Blackwell Scientific Publications, Oxford. (27s. 6d.).

The early chapters in this book consist of a brief discussion of the incidence, aetiology, $\frac{\mathrm{O}}{9}$ and physiological changes in diabetes; these are followed by a more lengthy account of $D$ diabetic ocular manifestations and a review of current concepts of pathogenesis. Prognosis under modern therapy, treatment, and complications are summarized and future research projects are suggested.

It is difficult, however, to appreciate the exact purpose of a book of this kind. The author tells us that it is presented primarily to aid the ophthalmologist in evaluating fundus changes and secondarily to inform both the patient and the internist of the diverse opinions of many investigators. To address a medical and lay audience at the same time without either irritating the former or bewildering the latter is no easy task-as this book shows. Thus the doctor is told somewhat naively that " diabetes may also be a metabolic disturbance" and that "many diabetic patients do not have visual disturbance", whereas 
the patient is unlikely to derive much encouragement from " investigations with radioisotopes of sodium, potassium, and chlorine show that movements of the ions through capillary walls and cell membrane are best explained in terms of active transfer ", nor may he altogether share the view that " the diabetic state gives rise to interesting organic changes ".

The book is poorly written, and when the author leaves the clinical field his text consists of snippets from the literature with little attempt to evaluate the material or to weave it into a coherent whole. It is not, therefore, suitable for the internist.

Of the six illustrations purporting to show pathological changes in the retina, only one (Fig. 10) could be accepted as demonstrating the claims of the legend, and the simplified diagrams of metabolic pathways are probably of little value to the reader for whom they were designed. The author presents no original data and his suggestions for future research, such as "Nutrition and disease and how they affect the body tissues", are so all-embracing and vast in scope as to appal the keenest research worker seeking here for inspiration. It is unfortunate that the book cannot be recommended, for it is beautifully produced and singularly free from printer's errors.

Viral and Rickettsial Diseases of the Skin, Eyes, and Mucous Membranes of Man. By H. Blank and G. RaKe. 1955. Pp. 285, 63 figs, 6 col. pl. Churchill, London. (60s.).

In a short text the authors have attempted to give an outline of the main viral infections occurring in these sites in man, with the inevitable result that many diseases which might have been mentioned are omitted. However, those conditions with which the book deals are presented in a readable manner and should prove instructive to those requiring an introduction to the subject.

A serious criticism of the work is the arrangement and classification of the material. Thus there seems little merit in separating Psittacosis from the remainder of Chlamydozoacae, while it is unusual to find dengue and infectious mononucleosis included with the exanthemata.

The book is extremely well produced and the illustrations are of a very high standard. A series of the references considered to be of greatest importance is added at the end of each section.

\section{NOTES}

\section{INTERNATIONAL Council of OphThaLmology}

The following were present at a meeting held in Paris on May 7, 1955: Duke-Elder (President), Berens (Vice-President), Hartmann (Secretary), Amsler (Treasurer), Bietti (International Organization against Trachoma), Franceschetti (Association for the Prevention of Blindness), Samuels (President of the last Congress), Coppez (President of the next Congress), Arruga (Spain), Charamis (Greece), Palomino Dena (Mexico), Paufique (France), Thiel (Germany), Weve (Holland).

Apart from dealing with current business, the following are the most important decisions taken by the Council.

1. Index Ophthalmologicus.-In accordance with the Statutes of the Council, an Index Ophthalmologicus had been published at the time of the International Congress in 1954. The sale of the Index had, however, up to the present been very slow, involving the Council in considerable expense. It was thought that this was due to the fact that it was insufficiently known. The Index contains the names and addresses of ophthalmologists in most countries of the world and information on hospitals, journals, and ophthalmological societies in these countries. It may 